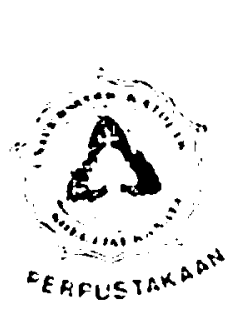

\title{
CELIE: A PORTRAYAL OF AN AFRO-AMERICAN WOMAN'S REJECTION OF TRADITIONAL VALUES ${ }^{\prime}$
}

\section{Ekawati Marhaenny Dukut ${ }^{2}$ and Nuki Dhamayanti ${ }^{3}$}

Abstract: The world of literature can be a medium of expressing the writer's expressions and ideas. Universal topics such as, love, death, and war often become subject matters in the world of literature. In the novel. of The Color Purple. Alice Walker describes the oppression experienced by AfroAmerican women in the female characters of Celie, Netrie, Shug Avery. Sofia, and Mary Agnes who faced sexual discriminations in a patriarchal society. Womanhood, education, and lesbianism are factors that help the AfroAmerican women to free themselves from traditional values. The Color Purple puts into words the process of is main character, Celie, who tries to reject and escape from the male domination of her world. The other AfroAmerican women characters that help Celie to find her selfidentity represent the manifestation of the rejection of the traditional values. This article, which uses the socio-historical and feminism approach, is intended to analyse the Afro-American women's rejection of traditional values by focusing on the major character of 'Walker's The Color Purple, Celie, as she develops from being a victim of traditional values to the rejoiceful discovery of her selfidentity.

Key words: Traditional values, patriarchal, AfroAmerican women's rejection.

1. This article is a development of the thesis defended at the Faculty of Letters, Soegijapranata Catholic University in 27 June 2002.

2 Dra. Ekawati Marhaenny Dukut, M.Hum. is a lecturer of the Faculty of Letters, Soegijapranata Catholic University, Sernarang.

3. Nuki Dhamayanti, S.S. is an alumni of the Faculty of Letters, Soegijapranata Catholic University, Semarang. 


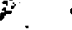

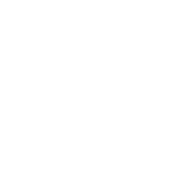

\section{INTRODUCTION}

It cannot be avoided that along with the development of a society comes the conflict of traditional versus modern values of a society. Based on Irving L. Gordon's (1984: 86) definition, women's traditional values are the values that show women's status. In America, women are portrayed to:

(a) be under the legal authority of their husbands or fathers,

(b) own property under certain circumstances, but upon marriage women surrendered control of their property to their husbands,

(c) be restricted economically to household and farm activities and denied equal opportunity in business and the professions,

(d) receive little schooling, limited to household tasks and moral training, or none at all, and were restricted in access to higher and professional education, and

(e) be denied the right to vote and otherwise participate in political affairs.

Whereas, in the modem values, with the development of education for both sexes, women began to think differently about themselves as beings who have more freedom to express their feelings, opinions, and dreams about their own life.

The author of The Color Purple, Alice Walker, is an AfroAmerican feminist, who wants to show how ludicrous it is to keep down a woman living in a modem society within the traditional values of working only as a housewife and a mother of children without any chance of experiencing any education at all. Aimed at Celie, the following statement "You black, you pore, you ugly, you a woman. Goddam, he say, you nothing at all" (Walker, 1982:176) accentuates the notion of an AfroAmerican woman as the lowest creature on earth. This idea is supported by Spaull and Millard, who believe that Celie is "the author's embodiment of a worthless female self, made monstrous through both her ugliness and the horror of her circumstances" (1989:144).

Written in epistolary form, that is "the narrative is conveyed entirely by an exchange of letters" (Abrams, 1988:119), Celie's communication, being only to God, also shows how unworthy she thinks of herself as a result of her father and husband's influential patriarchial upbringing. According to Mills,

Both the incestuous conception and loss of her children is the source of crushing guilt and loss of selfesteem. She accepts her oppression 
by her father and her husband because she is convinced she is worth no more (1986: 144).

Celie's letters seem to portray how at last she rejects the traditional values of being a woman and more specifically being an AfroAmerican woman.

\section{HISTORY OF AFROAMERICAN WOMEN}

The African culture applies a system of equality in their family lives. Changing of this system began after the establishment of the plantation system, which led to a basic justification for the trade of Africans into the American colonies as slaves. Beginning with the forced migration of millions of African women from the interior to the west coast of Africa, the history of AfroAmerican women in the United States started. Some waiting ships were readied to carry them away across the Atlantic Ocean to a new place named the West Indies, to plantations.

All efforts were made by the captors to put a stop to the continuing use of traditional African sultures such as, music, quilting and storytelling which were deeply rooted in the African women. They wanted to weaken any strength the slaves possessed, including their unity in culture.

There were several minority groups in the United States, but the African minorities were treated differently. The difference in treatment was to both African men and women. They had no rights to be independent and free people. This fact underscored a distinct difference in the treatment of African women with the European immigrant women.

During the era of the American revolution, there was an open chance for AfroAmerican women to gain their freedom. The population of free African women that joined the abolition movement grew rapidly. This is stated by Mankiller below:

From the 1830s to the onset of the Civil War they formed societies, supported abolitionist newspapers, lectured, wrote books, served on vigilante committees and worked within the Underground Railroad system. For over three decades women such as Maria Stewart, Sojoumer Truth, and Francis Ellen Watkins Harper raised their voices and wrote against the tyranny of slavery (1998: 13).

In addition to women's involvement in the revolution era as stated beforehand, the AfroAmerican women also survived their enslavement in 


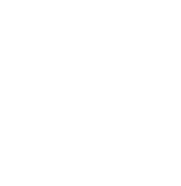

many ways, i.e. taking control over the nurture extended family, supporting the female network, and implanting the Christian teaching, but the most important way was through strengthening the sister's bond between AfroAmerican women.

\section{AFROAMERICAN FEMINISM}

The word feminism is usually seen as the modern movement to change the form of old male dominant values and create a new future perspective of women to see them as human beings not women. The word feminism refers to the ideology of women's emancipation, which rejects the way of the world's treatment over women because of their gender.

Based on Widyastuti (2001: 26) who quotes Andersen, women were considered to be under the domination of men and in addition, women were considered inferior, socially and legally, and were called minors. Women were under control of their father before they got married and then, having married, had to obey their husband's will. Since slavery time, the AfróAmerican women in the United States have always been aware of and struggled to face their condition of oppression related to their racial identity, class, status, and gender.

In the early 1800 s, some AfroAmerican women were given the chance to speak about their rights in the abolitionist cause. They tried to show their gender oppression because AfroAmerican women had a unique treatment as a racism case:

The search for the distinguishing features of an alternative epistemology used by AfricanAmerican women reveals that values and ideas that Afficanist scholars identify as being characteristically 'Black' often bear remarkable resemblance to similar ideas claimed by feminist scholars as being characteristically 'female' (Collins, 1993: 21).

This continued with the formation of 'The National Association of Colored Women', formed in 1896 that brought together more than one hundred Black women's clubs" (Mankiller, 1998: 202). In 1947, a novelist named Arm Petry produced an article entitled 'What's wrong with Negro men?" criticising the sexual abuse within the AfroAmerican community. Then in the 1960s,

the work of Black feminist writers and theorists, most notably Alice Walker, Ntozake Shange, and Michael WallacC led to national debates about sexual politics in the Black community (Mankiller, 1998 : 203). 
In the 1970s, the AfroAmerican women's movement appeared and was popularised by the 'Black Feminism' term, which aims to stay ${ }^{\text {Ffitives }}$ rejecting the old traditional values.

\section{THE COLOR PURPLE'S CELIE}

Alice Walker wrote The Color Purple, published in 1982 with Celie as the major character as well as the main narrator, who presents her experiences in an epistolary form. The seventy-one letters of Celie traces her journey from the repression due to her society's traditional values up to her rejection of those same traditional values.

Celie is the main character of The Color Purple. It is an epistolary novel and Celie (and Nettie, to a lesser extent) is the narrator. The capacity of her as herself was not shown until Alphonso mentions her name. Thus, we can see that she is under the influence of traditional values. Alphonso treats her as a mere object that has no control over her own destiny. This oppression gives Celie her low selfesteem. This lack of selfrespect appears when she can hardly say a man's name. She only says 'he' or Mr. ('ater Mr. is identified as Albert), which s'uggests her subordination and fear of him. She has neither identity nor voice this is the introduction of Celie (Walker, 1982:9).

Celie is raped at the age of fourteen by the man that is supposed to be her father (but later we learn that Alphonso is actually her stepfather). She gave birth to two children who are raised by somebody else. She is also convinced by her father and Albert her husband that she is not worthy of anything, not even to be a person in this world. The sexual abuse from her stepfather produces some negative effects, such as "difficulty in trusting others" (Mankiller, 1998: 610). This is why Celie can only write her pain to the two persons that she trusts deeply, i.e. God and Nettie, her sister.

Alphonso is the first person that speaks in the novel with his threat to Celie: "You better not never tell nobody but God. It'd kill your mammy" (Walker, 1982: 34). Looking over his words, Alphonso does not only take her virginity but her voice, too. Alphonso dominates her and orders her around, and Celle, fully submerged in a traditionally valued life, does as he says.

As a young girl, Celie still wants to have and enjoy her childhood, but at that time, she is forced to do the housework because her mother is sick. She has nobody to hold with whom she can share her pain. Consequently, 
she expresses her feelings in letters addressed to God, and, as instructed by Alphonso, only to Him. Although she hates her parents, she cannot reject the Christian doctrine of obeying parents. Celie just pretends that what has happened to her is normal. She always finds a way to rationalize her parent's flaws.

I used to git mad at my marnmy cause she put a lot of work on me. Then I see how sick she is. Couldn't stay mad at her. Couldn't be mad at my daddy cause he my daddy. Bible say, honor father and mother no matter what. Then after while every time I got mad, or start to feel mad, I got sick. Felt like throwing up. Terrible feeling. Then I start to feel nothing at all (Walker, 1982: 39).

Celie's feelings when her children are taken away are also not as strong as one would expect, where very little grief, if any, is apparent. There is a greater effect on her mother, when Celie's confessions to her of being raped directly bring her death upon her. She has been ill too long and is, therefore, too weak to face the condition of Celie who was raped by somebody that she does not know. It causes Alphonso to grieve and blame Celie. He. says "I'm evil an always up to no good", which is the reason why he takes the "other little baby, a boy this time" (Walker, 1982:4). She is completely controlled by her father. The following quotation exemplifies this:

Pa call me. Celie, he say. Like it wasn't nothing. Mr. want another look at you. I go stand in the door. The sun shine in my eyes. He's still up on his horse. He look me up and down. Pa rattle his newspaper. Move up, he won't bite, he say. I go closer to the steps, but not too close cause I' $m$ a little scared of his horse. Turn round, $\mathrm{Pa}$ say. I turn round (Walker, 1982: 12).

Alphonso is the head of Celie's family and traditionally holds authority. Alphonso also mentions that Celie has advantages for Albert to take care of the house and she will not reject anything Albert says. Alphonso disrespectfully mentions it in his rude sentences:

She ugly. Alphonso say. But she ain't no stranger to hard work. And she clean. And God done fixed her. You can do everything just like you want to and she ain't gonna make you feed it or clothe it (Walker, 1982: 910). 
The last of these lines even suggests her future husband, Albert to have her easily governed that he can even have children by her without having to keep them (as has already happened twice). Alphonso repeated his authoritativeness over Celie again in the following:

She ugly. Don't even look like she kin to Nettie. But she'll make the better wife. She ain't look smart either, and I'll just be fair, you have to watch her or she'll give away everything you own. But she can work like a man. Mr. _ say. How old she is? He say, She near twenty. And another thing She tell lies (Walker, 1982:10).

In so doing Alphonso takes all of Celle's pride and self-respect by criticising her looks and integrity. The traditional values can be seen in Alphonso who decides most of the things in Celie's life. She has to do the housework and replace her mother in taking care of Celie's younger brothers and sisters. She should fulfill Alphonso's sexual needs. From the explanation, we get the impression that Afro-American men like to govern AfroAmerican women's lives.

As a wife of Albett and a mother of four children, unfortunately, Celie has no voice either. However, Celie is the representative of an ideal housewife as well as an example of the traditional value, which according to Widyastuti (2001:27) "still believed that a woman's most sacred duty was to be the angel of the house". Widyastuti quotes Dix that,

a husband expected a wife to assume all authority and management of the home and family. He did not want to be bothered about the house. When he made the money, he felt that he had done his whole duty, and he left the rest to his wife. It was the same way with the children. Taking care of the children was not considered as male's job because his duty was to support the family financially (2001: 27).

This condition makes her weaker as a mother. Celie becomes powerless to stand against Albert's children. The eldest of these children is Harpo, while the other three remain nameless throughout the book. Mr. children all bright but they mean. They say Celie, I want dis. Celie, I want dat. Our Mama let us have it. He don't say nothing. They try to get his tention, he hide hind a puff of smoke. Don't let them run over you, Nettle say. You got to let them know who got the upper hand. They got it, Celie say. But Nettie keep on. You got to fight. All Celie know how to do is stay alive (Walker, 1982:17). 
Like that shown in the previous quotation, unfortunately for Celie, the family she cares for now seems no different than the one she's just left.

\section{THE DEVELOPMENT AND CHANGE OF CELE}

The first signs of change in Celie's circumstances revolve around when a new character, a woman named Shug Avery changes Celie's life into that of an independent woman, is firstly brought to our attention through a photograph. Shug is a blues singer who in the past was Albert's lover. Celie first learns about her from a picture that Alphonso's new wife, Celie's new 'stepmother', obtains. She keeps thinking about the image in the picture at night when she is making love with Albert. At that time she pretends to be Shug Avery and tries to enjoy the sexual intercourse, "I know what he doing to me he done to Shug Avery and maybe she like it. I put my arm around him" (Walker, 1982:13). It is only in this time, however, that there is a slight suggestion of not just submitting her body to her husband, but of being an equal part of lovemaking.

Soon Shug Avery is actually present in Albert's house when she is "sick and nobody in this town want to take the Queen Honeybee in" (Walker, 1982:40). Albert brings her home to live in his house until she can recover form her illness. On arrival, "You sure is ugly" are the first words Shug says to Celie, possibly an expression of jealousy to Albert's wife. So at first she treats Celie like everybody else has treated her, with a lack of respect, but gradually she befriends Celie and begins, directly and indirectly, to change her life. Her presence not only changes Celie's life, but also Albert's life in his relationship with Celie. It can be seen in the following quotation of The Color Purple, "You don't want her here, just say so, he say. Won't do no good. But if that the way you feel... He don't finish" (Walker, 1982:43). It can be seen here, that it is the first time Albert shares his mind with Celie. He consults Celie if she minds having Shug in the house. This shows Shug's power over him and for the first time. Celie notices how women may have power or control over men. Celie witnesses how strong Shug is in controlling what Albert does. This control of Shug's is proven strong enough to affect the physical domination Albert has over Celie when Shug says that she will not leave "until [Shug] know Albert won't even think about beating Celie" (Walker, 1982: 67).

The pair becomes closer when Harpo recruits Shug as a singer in his jukejoint where Shug sings "Miss Celie's song" (Walker, 1982:65). It flatters 
Celie and gives her self-confidence in front of her husband. This song indirectly shows the bond that now unites Shug and Celie. Celie is developing into an individual character, and this is highlighted when we find her in a position of superiority as a comfort for Shug when Shug breaks down and reveals some of her sadness and problems.

Much more dramatic is the development of the two characters's physical relationship. Indeed, throughout the novel, we find that Shug and Celie enjoy their lesbian relationship together. In The Color Purple this relationship is presented not in a repellent way, but appears like a sisterly relationship. Celie writes thus, "us sleep like sisters, me and Shug" (Walker, 1982:64) showing that their lesbian relationship is only another progression of their women's bond. It is very interesting to see how lesbianism is described not in terms of heterosexuality but as another form of female bonding.

Positioning herself as a sister, Shug Avery is quite surprised when she finds out that Celie never enjoys her sexual intercourse with Albert. For Shug, it is on the contrary. She really enjoys making love with Albert. Shug initially helps Celie to discover her sexuality. by showing her how to get pleasure by stimulating the clitoris. Kay's ${ }^{4}$ statement, cited in Mills says, the emotional side of the relationship between Shug and Celie, which is of importance and their lovemaking, is seen as an expression of this love. In other words, their relationship is seen to be of the same order as the relationship Celie has with her sister Nettie (1986:65).

From the discussion above, therefore, two points can be raised here that show Celie's rejection of traditional values. The first is the issue of masturbation that represents Celie as in charge of her own pleasure it is not just in the hands of a man. Second, the issue of lesbianism is raised, which is a theme perceived as closely related to feminism. The lesbian relationship, in this case, shows the rejection of a woman's dependence on a man because the woman replaces man's position. Except for the actual act of conception, lesbianism means to show that men are not necessary in the life of a woman.

Kay is one of the women who replied to the questionnaire about the Color Purple in a survey conducted by Mills. 


\section{CELIE'S FINAL TRANSFORMATION}

Celie's obsession with Shug starts her on the journey to find her identity. All of the things that she has in this world, i.e. her childhood, virginity, voice, mother, babies and Nettie, has been taken by Alphonso and Albert. In Shug, Celie finds somebody who appreciates her as a person who has a right to be who she wants, to say what is on her mind, to have the pleasure of sexual intercourse, and to decide what will happen to her own life.

Triggered by Shug's relationship, Celie begins changing into a new person, a person with values differing from the traditional values that she knows. She now recognizes herself as a person instead of just a 'thing'. She begins developing her emotional strength, so as to be used to release herself from Albert's grip, the hatred and joy she experiences on finding Nettie's letters. With Shug as the catalyst, Celie asks questions, does actions, and finally decides to leave Albert and "enter into the Creation" (Walker, 1982:170). Widyastuti (2001: 33) describes that the "decision to move out certainly surprised many people because it would be very uncommon and inappropriate for a married woman to live by herself, abandoning the family". Thus, it is understandable that Celie makes the decision to move out from her husband's home and live by herself as a free and independent woman to actualise her want of no longer to be under Albert's domination band become a woman of her own will.

The illustration of Albert's name as being $\mathrm{Mr}$ is transparent only up to page fortythree, henceforth, it shows Celie's commencement in rejecting her traditional values. The two different names used for Albert, i.e. Shug's "Albert" and Celie's "Mr. " symbolizes the differences between Celie and Shug - the difference between the oppressed and the powerful. This symbol is consistent throughout the book where Celie always refers Albert as $\mathrm{Mr}$ It is not until the final letter that Celie dares to call him Albert. It's Nettie, Albert say, gitting up. All the people down by the drive look up at us. They look at the house. The yard. Shug and Albert's cars. They look round at the fields. Then they commence to walk real slow up the walk to the house (Walker, 1982:243).

The above excerpt proves that Celie finally manages to transform herself from the oppressed position to being the powerful. Celie like Albert, in welcoming Nettie, at the end, shows her equally independent position of a person who controls her own life. 


\section{CONCLUSION}

The Color Purple is a portrayal of the AfroAmerican women's rejection of the traditional values of the malecentered domination. The male characters that are shown in The Color Purple are weak as individuals, but the power of the patriarchal system makes them strong and enables them to do whatever they want to do, especially with regard to treating AfroAmerican women as their property.

In addition to the men's expectation of women as housewives, The Color Purple also describes the sisterhood relationship among the women to minimize any feelings of oppression. Women's sacrifice can be seen through out The Color Purple as the continuing of sisterhood. Celie dressed herself up to protect Nettie from Alphonso's eye because Celie did not want the power that her stepfather had where he does anything he want including sexual abuse to be released on Nettie. We can also see how Shug Avery changes her plans to leave Albert's house and decides to stay until she knows that Celie can depend on the knowledge that Albert will not oppress her again. Shug Avery could just go and leave Celie to struggle in her oppressed life, but Shug knows that the unity of women will make her stronger against male power.

The unity of women that makes Celie and the other characters survive and be independent allows them a chance to speak up for their individual needs. Through the letters of Celie, for example, the unity of the women is considered as a female conspiracy against the male dominated surroundings. This female bond is also shown on a deeper, physical level by the acts of lesbianism portrayed in the novel. This, in turn, is a rejection of a woman's 'physical need' for a man. She can get pleasure from those of her own gender, and in The Color Purple - it is Celie's only source of sexual pleasure.

The fact that African heritage and specifically AfroAmerican women have no voice forced Alice Walker to struggle and support them through The Color Purple. Walker wants to show that AfroAmerican women have identity in this world. All they have to do is to speak up and put themselves in a position equal to men. Perhaps the most longlasting impression of this in The Color Purple is the huge change from oppression to independence of Celie and the portrayal of her improved life as a result of this. Thus, in other words, through The Color Purple Walker invites readers to reflect upon the constraints of the patriarchal system as a starting point to rejecting the AfroAmerican women's traditional values. 
140 Celt, Volume 2, Number 2, December 2002 : 129 - 140

\section{BIBLIOGRAPHY}

Abrams, M. H. A Glossary of Literary Terms. Orlando : Holt, Rinehart and Winston, Inc., 1988.

Collins, Patricia Hill. "The Social Construction of Black Feminist Thought". In Feminist Frontiers III. Laurel Richardson and Verta Taylor (ed). New York: McGrawHill, Inc., 1999, pp 20-30.

Irving, L. Gordon. American Studies : A Conceptual Approach. New York : Amsco School Publications, Inc., 1984.

Mills, Sara. "Authentic Realism". In Feminist Reading /Feminists Reading. Sara Mills, et al. (eds). New York : Harvester Wheatsheaf, 1986, pp 51-82.

Spaull, Sue and Elaine Millard. "The Anxiety of Authorship". In Feminist Readings/ Feminists Reading. Sara Mills, et al (eds). New York: Harvester Wheatsheaf, 1986, pp 122-152.

Walker, Alice. The Color Purple. New York: Harcourt Brace Jovanovich, 1982.

Widyastuti, Dewi. "Chopin's The Awakening: The Conflicts of Values About Women". In . Phenomenon, 5, 1, Yogyakarta: Universitas Sanata Dharma, 2001, pp 2435. 